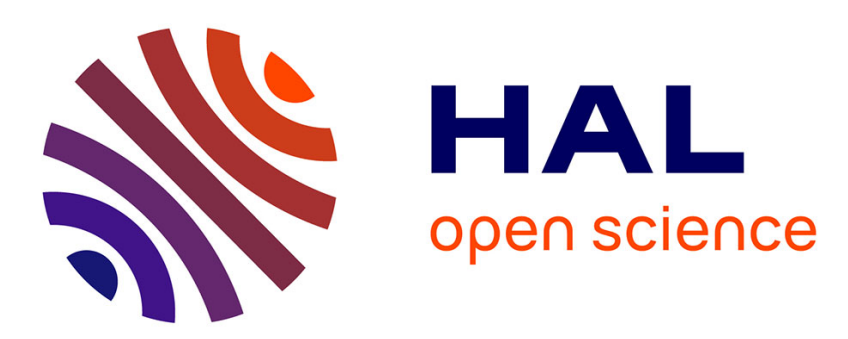

\title{
Five different phenotypes of endothelial cell cultures from the bovine corpus luteum: present outcome and role of potential dendritic cells in luteolysis
}

Katharina Spanel-Borowski

\section{- To cite this version:}

Katharina Spanel-Borowski. Five different phenotypes of endothelial cell cultures from the bovine corpus luteum: present outcome and role of potential dendritic cells in luteolysis. Molecular and Cellular Endocrinology, 2011, 10.1016/j.mce.2011.02.021 . hal-00693833

\section{HAL Id: hal-00693833 \\ https://hal.science/hal-00693833}

Submitted on 3 May 2012

HAL is a multi-disciplinary open access archive for the deposit and dissemination of scientific research documents, whether they are published or not. The documents may come from teaching and research institutions in France or abroad, or from public or private research centers.
L'archive ouverte pluridisciplinaire HAL, est destinée au dépôt et à la diffusion de documents scientifiques de niveau recherche, publiés ou non, émanant des établissements d'enseignement et de recherche français ou étrangers, des laboratoires publics ou privés. 


\section{Accepted Manuscript}

Title: Five different phenotypes of endothelial cell cultures from the bovine corpus luteum: present outcome and role of potential dendritic cells in luteolysis

Author: Katharina Spanel-Borowski

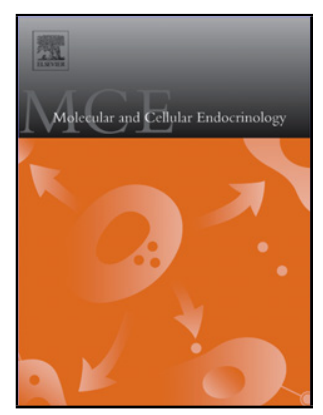

PII:

S0303-7207(11)00158-4

DOI: doi:10.1016/j.mce.2011.02.021

Reference: MCE 7784

To appear in: $\quad$ Molecular and Cellular Endocrinology

Received date: $\quad 12-2-2011$

Accepted date: $\quad$ 21-2-2011

Please cite this article as: Spanel-Borowski, K., Five different phenotypes of endothelial cell cultures from the bovine corpus luteum: present outcome and role of potential dendritic cells in luteolysis, Molecular and Cellular Endocrinology (2010), doi:10.1016/j.mce.2011.02.021

This is a PDF file of an unedited manuscript that has been accepted for publication. As a service to our customers we are providing this early version of the manuscript. The manuscript will undergo copyediting, typesetting, and review of the resulting proof before it is published in its final form. Please note that during the production process errors may be discovered which could affect the content, and all legal disclaimers that apply to the journal pertain. 


\section{Five different phenotypes of endothelial cell cultures from the \\ bovine corpus luteum: present outcome and role of potential dendritic cells in luteolysis}

Running title: Five phenotypes from the corpus luteum

\section{Katharina Spanel-Borowski}

Institute of Anatomy, University of Leipzig, Liebigstrasse 13, D-04103 Leipzig, Germany

Key words: steroidogenic luteal cells, vascular luteal cells, endothelial cells, dendritic cells, corpus luteum, luteolysis, innate immunity, adaptive immunity

Word count of main text (abbreviations, abstract, legends and references excluded): 4273

Corresponding author:

Katharina Spanel-Borowski, MD, Ph.D.

Institute of Anatomy, University of Leipzig, Liebigstraße 13, 04103 Leipzig, Germany;

telephone +49 341-9722053, fax +49 341-9722009

e-mail: spanelb@medizin.uni-leipzig.de 
Abbreviations

ac-LDL, acetylated low density lipoprotein; ADIM, adaptive immunity; 3 $\beta$-HSD, hydroxysteroid dehydrogenase; CK, cytokeratin; CL, corpus luteum; DCs, dendritic cells; FVIIIr, factor VIII related antigen; IFN- $\gamma$, interferon- $\gamma$; INIM, innate immunity; MHC, major histocompatiblity complex ; oxLDL , oxidized low density lipoprotein; PPRs, pattern recognition receptors; PRL, prolactin; ROS, reactive oxygen species; TLR, tolllike receptor; TLR4, toll-like receptor 4; TNF- $\alpha$, tumor necrosis factor $\alpha$; ZO-1, tight junction protein 


\section{ABSTRACT}

Progress in understanding the background of structural luteolysis depends on insights into the physiological function of innate immunity (INIM), in particular the presence of dendritic cells (DCs) in the corpus luteum (CL). For this reason, the cultures of five endothelial cell-like phenotypes derived from the bovine CL and their long-lasting analysis (morphology, function, and origin) become important. Types 1 and 2 represent microvascular endothelial cells with cytokeratin (CK) expression, assumed to be dangersensing cells. Types 3 and 4 express features of common endothelial cells. Type 5 indicates a steroidogenic cell type, which could be derived from steroidogenic $\mathrm{CK}^{+}$cells in the CL of development after loss of CK expression. Type 5 is a promising candidate to become a mature DC. It might act with the microvascular $\mathrm{CK}^{+}$cell/type 1 like a luteovascular unit, which connects INIM with adaptive/cell-mediated immunity (ADIM) in structural luteolysis.

\section{Contents}

1. Introduction

2. Cytokeratin-positive $\left(\mathrm{CK}^{+}\right)$type 1 cells

3. Cytokeratin-positive type 2 cells

4. Type 3 and 4 cells

5. Type 5 cells, metamorphosis from steroidogenic/luteal $\mathrm{CK}^{+}$cells into DCs, and similarities between microvascular type 1 and steroidogenic type 5

6. Microvascular and steroidogenic cells as luteovascular unit bridging INIM and ADIM in control of structural luteolysis

7. Clinical perspectives and concluding remarks

Acknowledgement

References

\section{Introduction}

The CL arises from the ruptured follicle wall. The transformation process depends on complex molecular patterns, which change during stages of development, secretion and regression (Stocco et al., 2007; Devoto 2009 et al., 2009). The bovine CL of regression 
looses the capillary bed and shunt-like arterioles become prominent. Proliferating monocytes are noted together with T cells (Spanel-Borowski et al., 1997; Reibiger and Spanel-Borowski, 2000; Bauer et al., 2001). The CL finally becomes a hyalinised scar known as corpus albicans in humans and in cows. It has been forwarded many years ago that the luteolytic process compares with an immunoregulatory event (Murdoch et al., 1988; Brännström and Friden, 1997). The possibility is now being substantiated by the exciting progress in understanding INIM function as highly beneficial for the body (Turvey and Broide, 2010). The detection of pattern recognition receptors (PRRs) on immunocompetent cells attributes INIM the capability to recognize clusters of lipids, lipoproteins, proteins and nucleic acids either from the outside or the inside (O'Neill and Bowie, 2007; Takeuchi and Akira, 2010). Among the four families of PRRs the toll-like receptor (TLR) family is well studied and the TLR4 receptor (TLR4) recognized as the binding site of oxidized low density lipoprotein (oxLDL). Ligands of PRRs like heat shock proteins, acute phase proteins, defensins, high mobility box group 1, S100 proteins are termed alarmins, because they are released from damaged/dead cells and represent danger signals (Matzinger, 2002; Bianchi, 2007). They are sensed by DCs, which respond with the multipurpose signaling cascade of inflammation for the release of cytokines and chemokines. In addition, specified cell processes/filipodia of DCs present the processed antigen together with the major histocompatiblity complex (MHC) to naïve T cells, which then differentiate into $\mathrm{T}$ cell subsets such as helper and suppressor/cytotoxic cells (Banchereau and Steinman, 1998, Steinman and Banchereau, 2007, Zhang and Zhang 2010). The DCs thus connect INIM with ADIM (Takeda and Akira, 2005; Iwasaki and Medzhitov, 2010).

The CL represents a heterogeneous cell population consisting of steroidogenic cells, microvascular cells, connective tissue cells and leukocytes. Fully luteinized steroidogenic cells and leukocytes do not survive in culture because of their high end stage of differentiation, whereas vascular cells and fibroblasts multiply and thus can be passaged. The mature $\mathrm{CL}$ is a young tissue with a still fragile cell cohesion. This explains the successful isolation of five endothelial cell-like phenotypes using a simple mechanical procedure (Spanel-Borowski, 1991; Spanel-Borowski and van der Bosch, 1990; Davis et al., 2003). The five phenotypes maintain a stable morphology in long-term culture also after deep-freezing. At first, the five phenotypes seemed to express the typical criteria of endothelial cells as there is the epithelial monolayer as sign of contact-inhibited growth, spontaneous tubule formation in vitro, expression of factor VIII related antigen (FVIIIr) 
and the uptake of acetylated low density lipoprotein (ac-LDL). This led to the concept that the cells are either from the arterious and the venous side of the microvascular bed or that different endothelial cells form a mosaic-like pattern. The search was thus intensified to attribute specific functions to the five phenotypes. The findings confirmed heterogeneity of endothelial cell cultures but also revealed inconsistencies. It became evident that type 5 cells were reminiscent of granulosa-like cells forming a monolayer in the absence of growth factors (Spanel-Borowski et al., 1994a; Spanel-Borowski et al., 1994c). That type 5 cells expresses similarities with type 1 cells has been registered without further interpretations (Fenyves et al., 1993). The retrospective analysis of own findings has generated a novel understanding for types 1 and 5 being potential immunocompetent cells for danger signal recognition (Spanel-Borowski, 2011a). Types 1 and 5 are presently judged as sentinels of INIM either in the vascular system or in the parenchyma of the CL. Both cells could become important tools to study the physiological side of INIM in control of luteolysis.

\section{Cytokeratin-positive type 1 cells}

Understanding the function of the $\mathrm{CK}^{+}$surface epithelium cells meets a continuous interest because of the ongoing debate on the origin of epithelial ovarian cell cancer (Auersperg et al., 2001; Kumar et al., 2009). On the contrary, the study of $\mathrm{CK}^{+}$follicle cells is widely neglected. In the fetal period, $\mathrm{CK}^{+}$follicle cells of primordial follicles arise from the medullar part of the sex cords of bovine and human ovaries (Löffler et al., 2000). In the adult period, CK expression transiently disappears in growing follicles, and reappears in granulosa cell subtypes of preovulatory follicles. After follicle rupture, steroidogenic $\mathrm{CK}^{+}$cells form peripheral zones in the $\mathrm{CL}$ of development, and gradually pass away between stages of secretion and regression (Fig. 1). The fading of steroidogenic $\mathrm{CK}^{+}$cells could explain the controversial reports displaying either presence or absence of $\mathrm{CK}^{+}$luteal cells in the human and bovine CL (Czernobilsky et al., 1985; Santini et al., 1993; Ricken et al., 1995). In addition to the steroidogenic $\mathrm{CK}^{+}$cells, a microvascular $\mathrm{CK}^{+}$type is revealed in the CL at the stage of secretion (Fig. 1). These cells, which are scattered within the endothelium of luteal capillaries and of septal venules, come up to roughly $1 \%$ of all $\mathrm{CK}^{+}$cells within a CL. Because a few single $\mathrm{CK}^{+}$cells can be disclosed in the septal area (previous thecal layer) of the developing CL, the possibility is forwarded that the microvascular $\mathrm{CK}^{+}$cells are derived from endothelial progenitor cells. Their 
ancestors could have been segregated as hemangioblasts from the ventral somite into the paraxial/intermediate mesoderm of the aorto-gonado-mesonephros region according to studies in the avian embryo (Dieterlen-Lièvre et al., 2006; Pouget et al., 2006). After separation into hematopoietic progenitor cells and angioblasts, angioblasts immigrate into visceral organs and likely into the genital ridge with the primitive ovary. By using the sophisticated gene tracing strategy for VE-cadherin-expressing hemangioblasts, VEcadherin positive endothelial cells are traced in the aorta, the liver, and the bone marrow of the midgestation mouse embryo (Zovein et al., 2008). In the adult mouse with the inducible VE-cadherin cell line, single positive endothelial cells are detected in various organs. Provided that the VE-cadherin positive endothelial cells co-express CK, they represent the rare subpopulation of $\mathrm{CK}^{+}$endothelial cells with ubiquitous occurrence and a still unknown function (Jahn et al., 1987; Patton et al., 1990; Mineau-Hanschke et al., 1993). The $\mathrm{CK}^{+}$endothelial cells should be distinguished from the $\mathrm{CK}^{+}$vascular smooth muscle cells described in the intima and the media and increasing with atherosclerotic progress (Johansson et al., 1997; Stintzing et al., 2009).

The epithelioid $\mathrm{CK}^{+}$type 1 cell might represent a steroidogenic cell derived from the early CL. This possibility is convincingly excluded. Type 1 cells lack the steroidogenic enzymes like $3 \beta$ hydroxysteroid dehydrogenase ( $3 \beta$-HSD) activity, steroidogenic acute regulatory protein as well as the mRNA for follicle stimulating hormone and for luteinizing hormone (Spanel-Borowski, 2011a). Yet the receptor mRNA for prostaglandin $\mathrm{F}_{2 \mathrm{a}}$ and $\mathrm{E}_{2}$, for vascular endothelial cell growth factor 2 as well as for Tie-2 (binds angiopoietin 1 and 2) compares type 1 cells with endothelial cells as does the isomorphic cobble-stone like monolayer, the uptake of ac-LDL, the diffuse expression of FVIIIr and the presence of $\alpha_{2}$ macroglobulin (Spanel-Borowski. 2011a).

The $\mathrm{CK}^{+}$type 1 cell seems to be cut out for special functions. The dense array of microvilli at the ultrastructural level speaks for high resorption activity, and discontinuities of the apical plasma membrane, which are associated with concanavalin A positive vesicles, might indicate the morphological correlate of ectocytosis (Herrman et al., 1996). It is considered as nonclassical protein-trafficking through exosomes (not through rough endoplasmic reticulum and Golgi-apparatus) and could stand for the still unclear secretion of leaderless proteins comprising many alarmins/danger signaling factors (Bianchi, 2007; Rock et al., 2010). Type 1 shows a peripheral ring of actin filaments, a vimentin network as well as abundant microtubules. Among them acetylated $\alpha$-tubulin forms the nonmotile single cilium (Wolf and Spanel-Borowski, 1992), which is 
no longer considered to be a nonfunctional evolutionary relict, but as a mechano-and chemosensory organelle. Because the ciliary proteins are implicated in signal transduction and morphogenetic pathways (Davis et al., 2006; Singla and Reiter, 2006), the single cilium could be the danger sensor like an antenna. Type 1 cells offer the unique possibility to study whether selective danger receptors/PRRs are expressed by the single cilium. Type 1 cells thus could become a unique endothelial cell type, also because of its surprising response to treatment with interferon- $\gamma($ IFN- $\gamma, 200 \mathrm{u} / 0.5 \mathrm{ml}$ for three days). Whereas IFN- $\gamma$ is detrimental for common endothelial cells (Stolpen et al., 1986; Friesel et al., 1987), the cytokine does not harm confluent type 1 monolayer but reinforces specific cell-cell contacts. Tight junctions proteins like occludin and ZO-1 are upregulated as are adherens junction proteins to name plakoglobin, desmoplakin, desmoglein and Ecadherin (Ricken et al., 1996). By contrast, the gap junction protein connexin 43 decreases. Interferon- $\gamma$ is judged as key cytokine with mighty influence DC function (Billiau and Matthys, 2009; Rojas and Krishnan, 2010). The cytokine could mediate the development of specific cell contacts to generate a microenvironment for limited molecule communication. The formation of tight junctions is reported for DCs when migrating through the gut epithelium (Rescigno et al., 2001) It is noteworthy that epithelioid $\mathrm{CK}^{+}$cell cultures from the ovarian surface epithelium display an IFN- $\gamma$ dependent response, which is similar to cell-cell contact increase in treated $\mathrm{CK}^{+}$type 1 cells (Spanel-Borowski, 2011a). The similarity in function between the two $\mathrm{CK}^{+}$cell types might be dated back to a shared phylogenetic origin in the aorta-gonadomesonephric region as explained above. It is noteworthy that in vitro $\mathrm{CK}^{+}$colonies are obtained in similar numbers from the bovine CL comparing stages of development, secretion and regression (Spanel-Borowski, 2011a). The observation speaks for the presence of microvascular $\mathrm{CK}^{+}$cells independent of the ovarian cycle and its endocrine function. Collectively, the $\mathrm{CK}^{+}$type 1 cells appear to be specialized endothelial cells with the capacity of a particular immunoresponse.

\section{Cytokeratin-positive type 2 cells}

The $\mathrm{CK}^{+}$type 2 cell cultures have endothelial cell criteria similar to type 1 culture, and supplementary findings. They are likely due to the cell isolation procedure strictly avoiding collagenase digestion to reduce fibroblast contamination. The mechanical disintegration seems to preserve desmosomes in microvessels (Spanel-Borowski, 1991). 
This leads to doublets of endothelial cells and vascular smooth-muscle cells. Both proliferate in vitro and spontaneously form three-dimensional tubules, which originate from a principal stem within the monolayer. Cells with the apical side towards the culture medium are aligned like a helix around the tubule centre containing extracellular matrix. The structure is reminiscent of the endothelial cell helix seen in vascular corrosion casts of small arterioles from the human ureter (Spanel-Borowski et al., 1992). Type 2 cells are thus a co-culture system and its origin attributed to arterioles within the CL septa. The in vitro cross-talk between two vascular cell types might give insight into the molecular demands for arteriole formation, maintenance and function. The aspect could become important when studying vasoconstriction in CL arterioles at the onset of luteolysis (Schams and Berisha, 2004). Given as marginal note, seldom occurring helical tubules in type 1 cultures are indicative of co-cultivation with vascular smooth muscle cells.

\section{Type 3 and 4 cells}

Capillaries of the CL have a key position in blood flow velocity and exchange of molecules. Capillaries are also a powerful paracrine factory for the production of growth factors and chemokines, and capillaries are the site for leukocyte recruitment (Stocco et al., 2007; Devoto et al. 2009). Inspite of the $40 \%$ of vascular cells in a CL, the isolation of endothelial cells using enzyme digestion of CL tissue or lectin-coated-magnetic beads often fails to obtain persistent protein expression in long-term culture (Acosta et al., 2005). In our hands, mechanical disintegration of peripheral tissue from the CL of secretion, followed by cell seeding into 24-well-plates at semi-clonal conditions leads to more than five healthy colonies of CK-negative ( $\left.\mathrm{CK}^{-}\right)$types 3 and 4 within 7-10 days (Spanel-Borowski, 2011a). The cell types behave like typical microvascular endothelial cells with many FVIIIr positive granules, abundant uptake of ac-LDL, and many pinocytotic vesicles at the basal cell side. The monolayer differs in phenotype being either spindle-shaped cells with a dominant single intracytoplasmic vesicle or round cells. Type 3 often switch morphology to type 4 after cell passage, which is explained by different proliferation rates during the recovery phase (Fenyves et al., 1993). Type 3 spontaneously develops a delicate three-dimensional network of tubules loosely tethered to the monolayer through delicate cell projections. The molecular control of tubule formation remains unclear. Type 4 displays a two-dimensional network, which is spread on the apical monolayer's side and discloses apoptotic cells. Thus, specific growth factor 
conditions seem in favor of intact tubule formation in type 3 cells, but insufficient in type 4 culture. Cell cultures type 3 and 4 are considered as models for the analysis of healthy and impaired in vitro tubule formation. In analogy, a different molecular pattern is likely active for an intact microvascular bed in the CL of secretion compared with the CL of regression. In contrast to type 1, types 3 and 4 show cell senescence and death under the treatment with IFN- $\gamma$, which is typical for endothelial cells. Types 3 and 4 have been successfully studied by diverse laboratories for presence and regulation of angiotensin II, endocrine gland vascular endothelial cell growth factor/prokineticin-1, and for the endothelin system (Hayashi et al., 2000; Klipper et al., 2004; Kisliouk et al., 2005).

\section{Type 5 cells, metamorphosis from steroidogenic/luteal $\mathrm{CK}^{+}$cells into DCs, and similarities between microvascular type 1 and steroidogenic type 5}

The conspicuously flat monolayer of type 5 cells was explained by a venous endothelium origin at first (Spanel-Borowski, 1991; Spanel-Borowski and van der Bosch, 1990). A closer look displayed unique long processes overlapping from cell margins as well as lipid droplets. The monolayer changed into a multilayer by growth factors derived from serum or co-cultivated types 3 or 4 (Spanel-Borowski et al., 1994c). Signs of steroidogenesis (density of lipid droplets, activity of $3 \beta-\mathrm{HSD}$, and progesterone concentration in the supernatant) were significantly elevated compared to basal levels. The big surprise that type 5 cultures looked like $\mathrm{CK}^{-}$granulosa cell cultures led to the name "granulosa-like cells" (Spanel-Borowski et al., 1994a). Because they are obtained from the CL of all stages, the granulosa-like cells obviously have escaped luteinisation, which conflicts with the common instruction that all granulosa cells become fully luteinized in the CL. The primary guess of an immature steroidogenic precursor cell, which supplies steroidogenic luteal cells in case of pregnancy, became doubtful because type 5 cells resisted fully luteinisation in culture.

The specific nature of type 5 cells is indicated by the positive response to the treatment with IFN- $\gamma$. Treated type 5 cells stay healthy, show mitotic figures, and increase Ncadherin-positive adherens junctions (Fenyves et al., 1994). Most of all, type 5 upregulates the MHC class II by 80 fold compared to basal level (Spanel-Borowski and Bein, 1993). The unique cytokine-responses compares with the typical response pattern of DCs (Banchereau and Steinman, 1998, Steinman and Banchereau, 2007; Zhang and Zhang, 2010). The well-illustrated concept is that type 5 cells are derived from 
preovulatory $\mathrm{CK}^{+}$granulosa cells showing the regulation of TLR4 and CD14 under $36 \mathrm{~h}$ of oxLDL treatment (Serke et al., 2009; Spanel-Borowski 2011a). Nonapoptotic cell death occurs and reactive oxygen species (ROS) are increased in these cultures. The $\mathrm{CK}^{+}$ follicle cells supposedly become steroidogenic $\mathrm{CK}^{+}$luteal cells in the bovine CL of development, which, according to fading intensity of CK immunostaining, gradually switch off CK expression in the stage of secretion (Fig. 1). The CL of pregnancy lacks any steroidogenic $\mathrm{CK}^{+}$cells. In analogy to the transient disappearance of CK expression in granulosa cells of growing follicles (Löffler et al., 2000), the same possibility is theoretically given for the CL system and would compare with the spontaneous loss of CK 8 gene expression in transformed cells (Knapp and Franke, 1989). Switching off one of the CK genes leads to the disappearance of CK filaments and to CK filamentdepending adhesions plaques. Their loss provides high cell mobility. The postulated cell metamorphosis could be caused by the depravation of the luteinizing hormone. Its effect on CK expression in granulosa cell cultures has been described (Ben-Ze'ev and Amsterdam, 1989). High persistent progesterone levels might also be involved. Our concept has missing links and requires further validation. In particular, type 5 cells have to be studied for the expression and regulation of TLRs by specific alarmins. The IFN- $\gamma$ dependent profile of cyto-and chemokines is wanted by studying the supernatants of activated type 5 cultures. As DCs have diverse surface antigens, the antigen-pattern analysis of type 5 should be conducted by using flow cytometry. The strongest antigen response in isolated cells then might allow the in situ localization of type 5 with immunostaining both in the cyclic CL and the CL of pregnancy. Fate mapping experiments with a CK19 knockin mouse line as developed by (Means et al. 2008) could give final evidence that $\mathrm{CK}^{+}$granulosa cells are converted into steroidogenic type 5 cells (Fig. 1).

Type 1 and type 5 cells depict similar features, which were recently summarized (Spanel-Borowski, 2011a): single cilium or single ciliary stub, uptake of ac-LDL, diffuse perinuclear response for FVIIIr immunostaining, peripheral ring of actin filaments, expression of the neuronal cell adhesion molecules 140, and comparable leukocyte adhesion after stimulation with phorbol myristate acetate. This observation could be explained by a shared phylogenetic origin in the aorta-gonado-mesonephric region with angioblasts in the mesenchyme (postulated to become microvascular type 1 cells) and with $\mathrm{CK}^{+}$sex cord cells to transform into follicle cells (postulated to become type 5 cells) as shown for the fetal ovary (Löffler et al., 2000). The aorta-gonado-mesonephric region 
is coined by the passage of primordial germ cells immigrating from the dorsal yolk sac through the dorsal mesogastrium into the genital ridge around week 6 in the human embryo (Sadler, 2000). A transient contact between germ cells, angioblasts and sex cord cells might imprint genes with the imperishable message to develop immunocompetence as vascular and steroidogenic cells in the adult ovary.

\section{Microvascular and steroidogenic cells as luteovascular unit bridging INIM and} ADIM in control of structural luteolysis

The audacious concept is forwarded that INIM has educated $\mathrm{CK}^{+}$cells as sentinel to conceive and immediately respond to danger signals in the micro-and macrovascular system through PRRs/TLRs like TLR4. Their activation triggers the powerful inflammatory cascade, which, in macrovessels, obviously contributes to atherosclerotic progress (Zhang YI and Zhang C, 2010; Miller et al., 2011). The $\mathrm{CK}^{+}$cell cultures, which were derived from the bovine aorta and vena cava and produce CK8, 18, and 19 as polypeptides (Spanel-Borowski et al. 1994b), could be comparable with the microvascular type 1 from the CL. In favor of the possibility are similarities between the macro-and microvascular $\mathrm{CK}^{+}$cells as have been demonstrated for the cytoskeleton and the intercellular contacts by using immunostaining (Fenyves et al., 1993; Spanel-Borowski et al., 1994b). In addition to the microvascular $\mathrm{CK}^{+}$cells, steroidogenic $\mathrm{CK}^{+}$cells represent the second cell type with potential danger sensing function in the CL. The statement relies on the surmise that the preovulatory $\mathrm{CK}^{+}$granulosa cells with an oxLDL-dependent TLR4 regulation continue their life as steroidogenic $\mathrm{CK}^{+}$cells in the developing $\mathrm{CL}$ for tissue reconstruction (Serke et al., 2009; Spanel-Borowski 2011b). In the CL stage of secretion with progesterone synthesis at its maximum, the steroidogenic $\mathrm{CK}^{+}$cells respond by getting a new costume without CK filaments (Fig. 1). In a broader sense, presence and absence of CK expression might be associated with a change in immunocompetence similar to immature DCs becoming mature DCs after migration to the antigen-presenting side (Banchereau and Steinman, 1998; Zhang YI and Zhang C, 2010).

Functional luteolysis with an acute interruption of progesterone synthesis occurs days before the onset of structural luteolysis in the bovine and human ovary. Monocytes and increasing numbers of $\mathrm{T}$ cells with dominance of cytotoxic T cells must be recruited before the decay of capillaries and the fatty degeneration of luteal cells (Brännström et al., 1993; Best et al., 1996; Bauer et al., 2001). It remains a mystery what really happens until 
structural luteolysis becomes evident (Stocco et al., 2007; Devoto et al., 2009). The scenario could be triggered by sudden ischemia due to vasoconstriction by e.g. prostaglandin $_{\mathrm{F} 2}$, endothelin-1, angiotensin II (Shirasuna et al., 2004). Ischemia harms common endothelial cells in the CL (Fig. 2). They secrete danger signals/alarmins being sensed and responded by microvascular $\mathrm{CK}^{+}$cells. The signaling cascade through TLRs then initiates inflammatory cytokines for the recruitment of monocytes, and naïve T cells. Interferon- $\gamma$ as key cytokine might activate adjacent steroidogenic "DCs" there promoting two signaling pathways (Billiau and Matthys, 2009). One might affect genes for the production of cytotoxic cytokines like tumor necrosis factor $\alpha$ (TNF- $\alpha$ ), which could damage steroidogenic and vascular luteal cells. The other pathway might induce the upregulation of the MHC complex for presenting the processed antigens (released from damaged luteal cells) to naïve $\mathrm{T}$ cells. $\mathrm{T}$ cell subsets and their actions could then modify the form of death-agony suffered by luteal cells and vascular cells. In the hamster CL, the apoptotic form is the dominant form, whereas in human CL the autophagic and luteolytic form of cell death is described (Gaytán et al., 2001a; Del Canto et al., 2007; Gaytán et al., 2008). Collectively, there is reason to believe that steroidogenic cells/type 5 cells converted from $\mathrm{CK}^{+}$cells bridge INIM and ADIM in the luteolytic process (Fig. 2). In follicular rupture, INIM function seems to dominate (Spanel-Borowski, 2011b).

Provided luteolysis compares with a sterile chronic inflammation (Medzhitov, 2008, 2010), the precisely limited immunoresponse to the CL's site seems to require the absence of mast cells. They are considered as critical mediators of ADIM functions (Kalesnikoff and Galli, 2008), and, in the ovary, are in fact restricted to the interstitial cortical tissue and to the medulla (Reibiger and Spanel-Borowski, 2000; Heider et al., 2001). Garbage removal by macrophage phagocytosis and connective tissue substitution are judged as the final steps of luteolysis. In other words, the luteolytic show starts at the level of the microvascular $\mathrm{CK}^{+}$cell together with the steroidogenic/type 5 cell. They are introduced as luteovascular unit with a rapid simultaneous response to focal ischemia. The postulated unit might requires pericytes, which are known to exert immunologic defense in addition to other functions (Fisher, 2009). The suggested luteovascular unit compares with the ischemia-sensitive neurovascular unit consisting of microvessels, neurons and glial cells (del Zoppo, 2010). As long as the luteovascular unit remain quiescent, the endocrine function of the CL continues as is the case in pregnancy. The prolactin (PRL) -PRL receptor system could influence the suggested luteovascular unit, because the permissive action of PRL on the antigen-presenting function of monocyte-derived DCs is reported 
(Matera et al., 2001). Additionally, the luteolytic action of PRL is accepted in rodents, and might be related to the antiangiogenic $16 \mathrm{kDa}$ PRL fragment generated from extracellular cleavage by cathepsin D (Gaytán et al., 2001a; Nguyen et al., 2006). Type 5 cells produces cathepsin, full-length $23 \mathrm{kDa}$ PRL as well as the short $34 \mathrm{kDa}$ receptor form (Ricken et al., 2007; Erdmann et al., 2007). In retrospect, rapid luteolysis defined by segregation of luteal cell complexes into ruptured luteal microvessels in white-footed mice, which had been kept under short photoperiod, could rely on the antiangiogenic PRL action. Rapid luteolysis was increased under subcutaneous PRL treatment with $30 \mu \mathrm{g} / 0.1$ $\mathrm{ml}$ for 4 and 6 days (Spanel-Borowski et al., 1983).

\section{Clinical perspectives and concluding remarks}

The cyclic ovary is a site of precisely timed tissue damage and repair. Hidden in the endocrine system, INIM is considered as the driving force of follicle rupture (SpanelBorowski, 2011b). Furthermore, INIM together with ADIM might arrange the onset of structural luteolysis. The novel concept relies on many illustrations (Spanel-Borowski, 2011a) and is here heightened in details. Different fine-tuning of immunoresponses could explain why, in the hamster ovary, CLs completely disappear within one ovarian cycle (Spanel-Borowski and Heiss, 1986; Gaytán et al., 2001b), whereas regressing stages are seen for several cycles in ovaries of rats, cows and human. Luteal cysts and the persistence of a CL, which leads to a prolonged ovarian cycle, might be explained by immunemediated failure. The premature immunoregulation of luteolysis could lead to CL insufficiency with failed or delayed implantation, and pregnancy loss (Erlebacher et al., 2004). The authors note in a mouse model that the blockade of CD40 (TNF receptor superfamily member involved in the adaptive immunoresponse) overactivated INIM, while progesterone synthesis was impaired and PRL stimulation failed. This points to the influence of the PRL-PRL receptor system on the luteolytic immunoregulation. The autoimmune damage leading to premature ovarian failure in women under 40 years of age might also represent a disturbed interaction between INIM and ADIM, because patients show altered T cell subsets and T cell-mediated cell injury (Vujovic, 2009).

Time has provided tremendous progress in understanding the molecular pattern of luteolysis and the function of INIM in sterile inflammation like in atherosclerosis and rheumatoid arthritis (Stocco et al., 2007; Devoto et al., 2009; Medzhitov, 2008, 2010). The exciting insights together with the thorough analysis of types 1-5 are the ground-line 
to validate the old speculation of .immunoregulated luteolysis (Murdoch et al., 1988).

Future experiments on receptor and cytokine regulation should include analysis of pericytes, which are obtained as byproduct by the cell isolation procedure from the bovine CL (Spanel-Borowski, 2011a). Much work lies ahead to convincingly proof the existence of a luteovascular unit and to understand the complexity of signaling pathways for immunoregulated luteolysis.

\section{Acknowledgement}

The article is dedicated to Prof. Wolfgang Kühnel in memory of my time at Lübeck, Germany, promoting the discovery of types 1-5.

\section{References}

Acosta, T.J., Tetsuka, M., Matsui, M., Shimizu, T., Berisha, B., Schams, D., Miyamoto, A., 2005. In vivo evidence that local cortisol production increases in the preovulatory follicle of the cow. J Reprod. Dev. 51, 483-489.

Auersperg, N., Wong, A.S., Choi, K.C., Kang, S.K., Leung, P.C., 2001. Ovarian surface epithelium: biology, endocrinology, and pathology. Endocr. Rev. 22, 255-288.

Banchereau, J., Steinman, R.M., 1998. Dendritic cells and the control of immunity. Nature 392, 245-252.

Bauer, M., Reibiger, I., Spanel-Borowski, K., 2001. Leucocyte proliferation in the bovine corpus luteum. Reproduction 121, 297-305.

Ben-Ze'ev, A., Amsterdam, A., 1989. Regulation of cytoskeletal protein organization and expression in human granulosa. Endocrinology 124, 1033-1041.

Best, C.L., Pudney, J., Welch, W.R., Burger, N., Hill, J.A., 1996. Localization and characterization of white blood cell populations within the menstrual cycle and menopause. Hum. Reprod. 11, 790-797. Hum. Reprod. 11, 790-797.

Bianchi, M.E., 2007. DAMPs, PAMPs and alarmins: all we need to know about danger. J. Leukoc. Biol. 81, 1-5.

Billiau, A., Matthys, P., 2009. Interferon-gamma: a historical perspective. Cytokine Growth Factor Rev. 20, 97-113.

Brännström, M., Friden, B., 1997. Immune regulation of corpus luteum function. Semin. Reprod. Endocrinol. 15, 363-370. 
Brännström, M., Mayrhofer, G., Robertson, S.A., 1993. Localization of leukocyte subsets in the rat ovary during the periovulatory. Biol. Reprod. 48, 277-286.

Czernobilsky, B., Moll, R., Levy, R., Franke, W.W., 1985. Co-expression of cytokeratin and vimentin filaments in mesothelial, granulosa and. Eur J. Cell. Biol. 37, 175-190.

Davis, E.E., Brueckner, M., Katsanis, N., 2006. The emerging complexity of the vertebrate cilium: new functional roles for an ancient organelle. Dev. Cell 11, 9-19.

Davis, J.S., Rueda, B.R., Spanel-Borowski, K., 2003. Microvascular endothelial cells of the corpus luteum. Reprod. Biol. Endocrinol. Nov 10;1, 89.

Del Canto F., Sierralta, W., Kohen, P., Munoz, A., Strauss, J.3., Devoto, L., 2007. Features of natural and gonadotropin-releasing hormone antagonist-induced corpus regression and effects of in vivo human chorionic gonadotropin. J. Clin. Endocrinol. Metab. 92, 4436-4443.

del Zoppo, G.J., 2010. The neurovascular unit, matrix proteases, and innate inflammation. Ann. N. Y. Acad. Sci. 1207, 46-49.

Devoto, L., Fuentes, A., Kohen, P., Cespedes, P., Palomino, A., Pommer, R., Munoz, A., Strauss, J.3., 2009. The human corpus luteum: life cycle and function in natural cycles. Fertil. Steril. 92, 1067-1079.

Dieterlen-Lièvre, F., Pouget, C., Bollerot, K., Jaffredo, T., 2006. Are intra-aortic hemopoietic cells derived from endothelial cells during ontogeny?. Trends Cardiovasc. Med. 16, 128-139.

Erdmann, S., Ricken, A., Merkwitz, C., Struman, I., Castino, R., Hummitzsch, K., Gaunitz, F., Isidoro, C., Martial, J., Spanel-Borowski, K., 2007. The expression of prolactin and its cathepsin D-mediated cleavage in the bovine corpus luteum vary with the estrous cycle. Am. J. Physiol. Endocrinol. Metab. 293, E1365-1377.

Erlebacher, A., Zhang, D., Parlow, A.F., Glimcher, L.H., 2004. Ovarian insufficiency and early pregnancy loss induced by activation of the innate immune system. J. Clin. Invest. 114, 39-48.

Fenyves, A.M., Behrens, J., Spanel-Borowski, K., 1993. Cultured microvascular endothelial cells (MVEC) differ in cytoskeleton, expression of cadherins and fibronectin matrix. A study under the influence of interferon-gamma. J. Cell. Sci. 106, 879-890.

Fenyves, A.M., Saxer, M., Spanel-Borowski, K., 1994. Bovine microvascular endothelial cells of separate morphology differ in growth and response to the action of interferongamma. Experientia 50, 99-104. 
Fisher, M., 2009. Pericyte signaling in the neurovascular unit. Stroke 40, S13-5.

Friesel, R., Komoriya, A., Maciag, T., 1987. Inhibition of endothelial cell proliferation by gamma-interferon. J. Cell. Biol. 104, 689-696.

Gaytán, F., Bellido, C., Morales, C., Sanchez-Criado, J.E., 2001a. Luteolytic effect of prolactin is dependent on the degree of differentiation of luteal cells in the rat. Biol. Reprod. 65, 433-441.

Gaytán, F., Morales, C., Bellido, C., Aguilar, R., Sanchez-Criado, J.E., 2001b. The fate of corpora lutea in the cyclic golden hamster. Gen. Comp. Endocrinol. 121, 104-113.

Gaytán, M., Morales, C., Sanchez-Criado, J.E., Gaytán, F., 2008. Immunolocalization of beclin 1, a bcl-2-binding, autophagy-related protein, in in the human ovary: possible relation to life span of corpus luteum. Cell Tissue Res. 331, 509-517.

Hayashi, K., Miyamoto, A., Berisha, B., Kosmann, M.R., Okuda, K., Schams, D., 2000. Regulation of angiotensin II production and angiotensin receptors in microvascular endothelial cells from bovine corpus luteum. Biol. Reprod. 62, 162-167.

Heider, U., Pedal, I., Spanel-Borowski, K., 2001. Increase in nerve fibers and loss of mast cells in polycystic and postmenopausal ovaries. Fertil. Steril. 75, 1141-1147.

Herrman, G., Missfelder, H., Spanel-Borowski, K., 1996. Lectin binding patterns in two cultured endothelial cell types derived from bovine corpus luteum. Histochem. Cell. Biol. 105, 129-137.

Iwasaki, A., Medzhitov, R., 2010. Regulation of adaptive immunity by the innate immune system. Science 327, 291-295.

Jahn, L., Fouquet, B., Rohe, K., Franke, W.W., 1987. Cytokeratins in certain endothelial and smooth muscle cells of two taxonomically distant vertebrate species, Xenopus laevis and man. Differentiation 36, 234-254.

Johansson, B., Eriksson, A., Virtanen, I., Thornell, L.E., 1997. Intermediate filament proteins in adult human arteries. Anat. Rec. 247, 439-448.

Kalesnikoff, J., Galli, S.J., 2008. New developments in mast cell biology. Nat. Immunol. 9, 1215-1223.

Kisliouk, T., Podlovni, H., Spanel-Borowski, K., Ovadia, O., Zhou, Q.Y., Meidan, R., 2005. Prokineticins (endocrine gland-derived vascular endothelial growth factor and BV8) in the bovine ovary: expression and role as mitogens and survival factors for corpus luteum-derived endothelial cells. Endocrinology 146, 3950-3958. 
Klipper, E., Gilboa, T., Levy, N., Kisliouk, T., Spanel-Borowski, K., Meidan, R., 2004. Characterization of endothelin-1 and nitric oxide generating systems in corpus luteumderived endothelial cells. Reproduction 128, 463-473.

Knapp, A.C., Franke, W.W., 1989. Spontaneous losses of control of cytokeratin gene expression in transformed, non-epithelial human cells occurring at different levels of regulation. Cell 59, 67-79.

Kumar, H., Kawai, T., Akira, S., 2009. Toll-like receptors and innate immunity. Biochem. Biophys. Res. Commun. 388, 621-625.

Löffler, S., Horn, L.C., Weber, W., Spanel-Borowski, K., 2000. The transient disappearance of cytokeratin in human fetal and adult ovaries. Anat. Embryol. 201, 207-215.

Matera, L., Mori, M., Galetto, A., 2001. Effect of prolactin on the antigen presenting function of monocyte-derived dendritic cells. Lupus 10, 728-734.

Matzinger, P., 2002. The danger model: a renewed sense of self. Science 296, 301-305.

Means, A.L., Xu, Y., Zhao, A., Ray, K.C., Gu, G.,2008. A CK19(CreERT) knockin mouse line allows for conditional DNA recombination in epithelial cells in multiple endodermal organs. Genesis. 46:318-323.

Medzhitov, R., 2008. Origin and physiological roles of inflammation. Nature 454, 428435.

Medzhitov, R., 2010. Inflammation 2010: new adventures of an old flame. Cell 140, 771776.

Miller, Y.I., Choi, S.H., Wiesner, P., Fang, L., Harkewicz, R., Hartvigsen, K., Boullier, A., Gonen, A., Diehl, C.J., Que, X., Montano, E., Shaw, P.X., Tsimikas, S., Binder, C.J., Witztum, J.L., 2011. Oxidation-specific epitopes are danger-associated molecular patterns recognized by pattern recognition receptors of innate immunity. Circ. Res. $108,235-248$.

Mineau-Hanschke, R., Patton, W.F., Hechtman, H.B., Shepro, D., 1993. Immunolocalization of cytokeratin 19 in bovine and human pulmonary microvascular endothelial cells in situ. Comp. Biochem. Physiol. Comp Physiol 104, 313-319.

Murdoch, W.J., Steadman, L.E., Belden, E.L., 1988. Immunoregulation of luteolysis. Med. Hypotheses 27, 197-199.

Nguyen, N.Q., Tabruyn, S.P., Lins, L., Lion, M., Cornet, A.M., Lair, F., Rentier-Delrue, F., Brasseur, R., Martial, J.A., Struman, I., 2006. Prolactin/growth hormone-derived 
antiangiogenic peptides highlight a potential role of tilted peptides in angiogenesis. Proc. Natl. Acad. Sci. U. S A. 103, 14319-14324.

O'Neill, L.A., Bowie, A.G., 2007. The family of five: TIR-domain-containing adaptors in Toll-like receptor. Nat. Rev. Immunol 7, 353-364.

Patton, W.F., Yoon, M.U., Alexander, J.S., Chung-Welch, N., Hechtman, H.B., Shepro, D., 1990. Expression of simple epithelial cytokeratins in bovine pulmonary microvascular endothelial cells. J. Cell. Physiol. 143, 140-149.

Pouget, C., Gautier, R., Teillet, M.A., Jaffredo, T., 2006. Somite-derived cells replace ventral aortic hemangioblasts and provide aortic smooth muscle cells of the trunk. Development 133, 1013-1022.

Reibiger, I., Spanel-Borowski, K., 2000. Difference in localization of eosinophils and mast cells in the bovine ovary. J. Reprod. Fertil. 118, 243-249.

Rescigno, M., Urbano, M., Valzasina, B., Francolini, M., Rotta, G., Bonasio, R., Granucci, F., Kraehenbuhl, J.P., Ricciardi-Castagnoli, P., 2001. Dendritic cells express tight junction proteins and penetrate gut epithelial monolayers to sample bacteria.. Nat. Immunol. 2, 361-367.

Ricken, A., Rahner, C., Landmann, L., Spanel-Borowski, S., 1996. Bovine endotheliallike cells increase intercellular junctions under treatment with interferon-gamma. An in vitro study. Ann. Anat. 178, 321-330.

Ricken, A.M., Spanel-Borowski, K., Saxer, M., Huber, P.R., 1995. Cytokeratin expression in bovine corpora lutea. Histochem. Cell. Biol. 103, 345-354.

Ricken, A.M., Traenkner, A., Merkwitz, C., Hummitzsch, K., Grosche, J., SpanelBorowski, K., 2007. The short prolactin receptor predominates in endothelial cells of micro- and macrovascular origin. J. Vasc. Res. 44, 19-30.

Rock, K.L., Latz, E., Ontiveros, F., Kono, H., 2010. The sterile inflammatory response. Annu. Rev. Immunol. 28, 321-342.

Rojas, D., Krishnan, R., 2010. IFN-gamma generates maturation-arrested dendritic cells that induce $\mathrm{T}$ cell hyporesponsiveness independent of Foxp3+ T-regulatory cell generation. Immunol. Lett. 132, 31-37.

Sadler. T.W., 2000. Langman's Medical Embryology. Eighth edition. Lippincott Williams\&Wilkins, Philadelphia.

Santini, D., Ceccarelli, C., Mazzoleni, G., Pasquinelli, G., Jasonni, V.M., Martinelli, G.N., 1993. Demonstration of cytokeratin intermediate filaments in oocytes of the developing and adult human ovary. Histochemistry 99, 311-319. 
Schams, D., Berisha, B., 2004. Regulation of corpus luteum function in cattle--an overview. Reprod. Domest. Anim. 39, 241-251.

Serke, H., Vilser, C., Nowicki, M., Hmeidan, F.A., Blumenauer, V., Hummitzsch, K., Losche, A., Spanel-Borowski, K., 2009. Granulosa cell subtypes respond by autophagy or cell death to oxLDL-dependent activation of the oxidized lipoprotein receptor 1 and toll-like 4 receptor. Autophagy 5, 991-1003.

Shirasuna, K., Asaoka, H., Acosta, T.J., Wijayagunawardane, M.P., Matsui, M., Ohtani, M., Miyamoto, A., 2004. Endothelin-1 within the corpus luteum during spontaneous luteolysis in the cow: local interaction with prostaglandin F2alpha and angiotensin II. J. Cardiovasc. Pharmacol. 44 Suppl 1, S252-255.

Singla, V., Reiter, J.F., 2006. The primary cilium as the cell's antenna: signaling at a sensory organelle. Science 313, 629-633.

Spanel-Borowski, K., 1991. Diversity of ultrastructure in different phenotypes of cultured microvessel endothelial cells isolated from bovine corpus luteum. Cell Tissue Res. 266, 37-49.

Spanel-Borowski, K., 2011a. Footmarks of innate immunity in the ovary and cytokeratinpositive cells as potential dendritic cells. In: Adv. Anat. Embryol. Cell Biol. Vol 209, Springer Heidelberg. ISBN 978-3-642-16076-9.

Spanel-Borowski, K., 2011b. Ovulation as danger signaling event of innate immunity. Mol. Cell. Endocrinol. 333, 1-7.

Spanel-Borowski, K., Bartke, A., Petterborg, L.J., Reiter, R.J., 1983. A possible mechanism of rapid luteolysis in white-footed mice, Peromyscus leucopus. J. Morphol. $176,225-233$.

Spanel-Borowski, K., Bein, G., 1993. Different microvascular endothelial cell phenotypes exhibit different class I and II antigens under interferon-gamma. In Vitro Cell. Dev. Biol. Anim 29A, 601-602.

Spanel-Borowski, K., Heiss, C., 1986. Luteolysis and thrombus formation in ovaries of immature superstimulated golden hamsters. Aust. J. Biol Sci. 39, 407-416.

Spanel-Borowski, K., Kuhri, P., Kuhnel, W., 1992. Endothelial cell helix in small arterioles of human ureters. A study by scanning electron microscopy (SEM). Ann. Anat .174, 213-216.

Spanel-Borowski, K., Rahner, P., Ricken, A.M., 1997. Immunolocalization of CD18positive cells in the bovine ovary. J. Reprod. Fertil. 111, 197-205. 
Spanel-Borowski, K., Ricken, A.M., Kress, A., Huber, P.R., 1994a. Isolation of granulosa-like cells from the bovine secretory corpus luteum and their characterization in long-term culture. Anat. Rec. 239, 269-279.

Spanel-Borowski, K., Ricken, A.M., Patton, W.F., 1994b. Cytokeratin-positive and cytokeratin-negative cultured endothelial cells from bovine aorta and vena cava. Differentiation 57, 225-234.

Spanel-Borowski, K., Ricken, A.M., Saxer, M., Huber, P.R., 1994c. Long-term co-culture of bovine granulosa cells with microvascular endothelial cells: effect on cell growth and cell death. Mol. Cell. Endocrinol. 104, 11-19.

Spanel-Borowski, K., van der Bosch, J., 1990. Different phenotypes of cultured microvessel endothelial cells obtained from bovine corpus luteum. Study by light microscopy and by scanning electron microscopy (SEM). Cell Tissue Res. 261, 35-47.

Steinman, R.M., Banchereau, J., 2007. Taking dendritic cells into medicine. Nature 449, 419-426.

Stintzing, S., Ocker, M., Hartner, A., Amann, K., Barbera, L., Neureiter, D., 2009. Differentiation patterning of vascular smooth muscle cells (VSMC) in atherosclerosis. Virchows Arch. 455, 171-185.

Stocco, C., Telleria, C., Gibori, G., 2007. The molecular control of corpus luteum formation, function, and regression. Endocr. Rev. 28, 117-149.

Stolpen, A.H., Guinan, E.C., Fiers, W., Pober, J.S., 1986. Recombinant tumor necrosis factor and immune interferon act singly and in combination to reorganize human vascular endothelial cell monolayers. Am. J. Pathol. 123, 16-24.

Takeda, K., Akira, S., 2005. Toll-like receptors in innate immunity. Int. Immunol. 17, 114.

Takeuchi, O., Akira, S., 2010. Pattern recognition receptors and inflammation. Cell 140, $805-820$.

Turvey, S.E., Broide, D.H., 2010. Innate immunity. J. Allergy Clin. Immunol. 125, S2432.

Vujovic, S., 2009. Aetiology of premature ovarian failure. Menopause Int. 15, 72-75.

Wolf, K.W., Spanel-Borowski, K., 1992. The interphase microtubule cytoskeleton of five different phenotypes of microvessel endothelial cell cultures derived from bovine corpus luteum. Tissue Cell 24, 347-354.

Zhang YI, Zhang C, 2010. Role of dendritic cells in cardiovascular diseases. World Journal of Cardiology Nov 26, s2, 357-364. 
Zovein, A.C., Hofmann, J.J., Lynch, M., French, W.J., Turlo, K.A., Yang, Y., Becker, M.S., Zanetta, L., Dejana, E., Gasson, J.C., Tallquist, M.D., Iruela-Arispe, M.L., 2008. Fate tracing reveals the endothelial origin of hematopoietic stem cells. Cell Stem Cell $3,625-636$. 


\section{Legends}

\section{Figure 1}

Two types of potential danger-sensing cells (steroidogenic, microvascular) are depicted in the developing CL (left), and the CL of secretory stage (right ) at low and high magnification $(a, b)$ and at cellular level (c). a:The gyrated structure of the young CL shows peripheral zonation formed by steroidogenic $\mathrm{CK}^{+}$cells (red). The fully differentiated CL contains uniformly distributed steroidogenic $\mathrm{CK}^{+}$cells with decreasing CK expression (red and pink). $\mathrm{b}$ and left: The microvascular $\mathrm{CK}^{+}$cell (red) associates with the sprouting vessel (green) in the forming septum as previous thecal cell layer; steroidogenic $\mathrm{CK}^{+}$cells in the former granulosa cell layer show a strong $\mathrm{CK}$ expression (red). $\mathrm{b}$ and right: Three microvascular $\mathrm{CK}^{+}$cells are attributed to vessels in the CL parenchyma. It also displays steroidogenic cells with a decreasing intensity of CK expression (red, pink and white). Signals are received from the microvascular $\mathrm{CK}^{+}$cell type (short arrows). c and left: The microvascular $\mathrm{CK}^{+}$cells becomes type 1 cell (doublelined arrows). $\mathrm{c}$ and right. The steroidogenic $\mathrm{CK}^{+}$cells convert into type 5 cells. After loss of CK expression long cell processes develop (broken arrows). Arrows indicate theoretical associations. Drawn by R. Spanel and adapted from Spanel-Borowski (2011a).

\section{Figure 2}

The concept of early structural luteolysis depends on the luteovascular unit, which connects INIM and ADIM function. A: Danger signals from ischemia-damaged common endothelial cells are sensed by the TLR-positive microvascular $\mathrm{CK}^{+}$cell equipped with a single cilium (red). The signaling cascade generates gateways either for recruitment of monocytes and T cells, or for IFN- $\gamma$ secretion. B: The cytokine affects the potential dendritic cell (pink). It is the steroidogenic cell with TLRs, which has converted from a steroidogenic $\mathrm{CK}^{+}$cell by loosing $\mathrm{CK}$ expression and developing long cell processes. Interferon- $\gamma$ activates the TNF- $\alpha$ gene, and the TNF- $\alpha$ protein harms a common steroidogenic cell (yellow, left side in C). Interferon- $\gamma$ also turns the converted cell into an antigen-presenting cell by upregulation of the MHC II complex. The antigen comes from the damaged steroidogenic cell in C. Naive T cells (blue) are trained into T cell subsets 
(green), which will induce cell death in the intact common steroidogenic cell (right side in C). Arrows represent theoretical associations. Drawn by R. Spanel 
Early structural luteolysis might depend on innate immunity function, in particular on the presence of dendritic cells in the corpus luteum. We characterize two out of five endothelialcell-like phenotypes as candidates of danger-sensing function. The concept is forwarded that the microvascular cytokeratin (CK) -positive type 1 and the steroidogenic type 5 after loss of CK form a luteovascular unit. It is activated by a rapid simultaneous response to focal ischemia and supplies the bridge to adaptive immunity. 


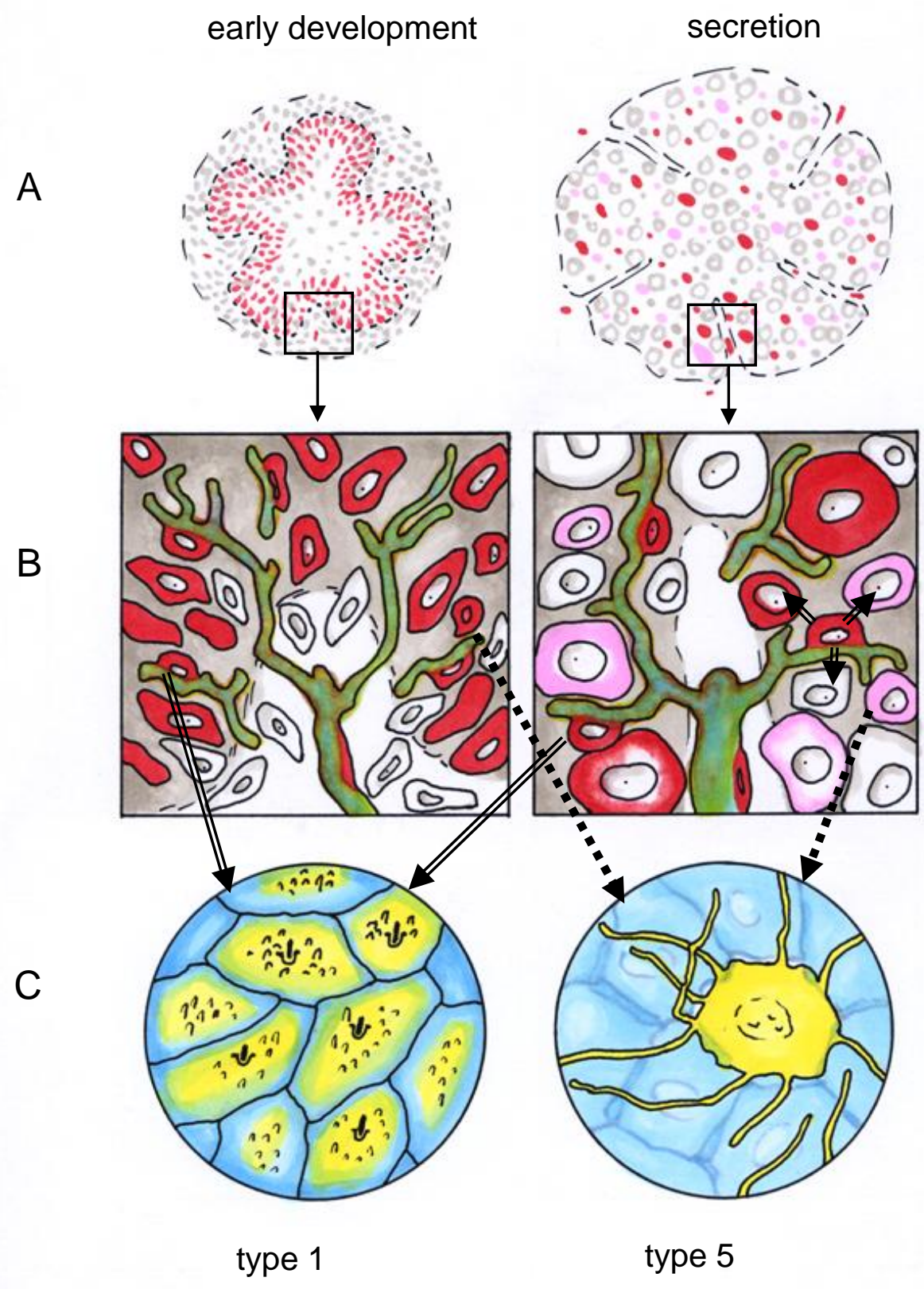

Fig. 1

Spanel-Borowski 


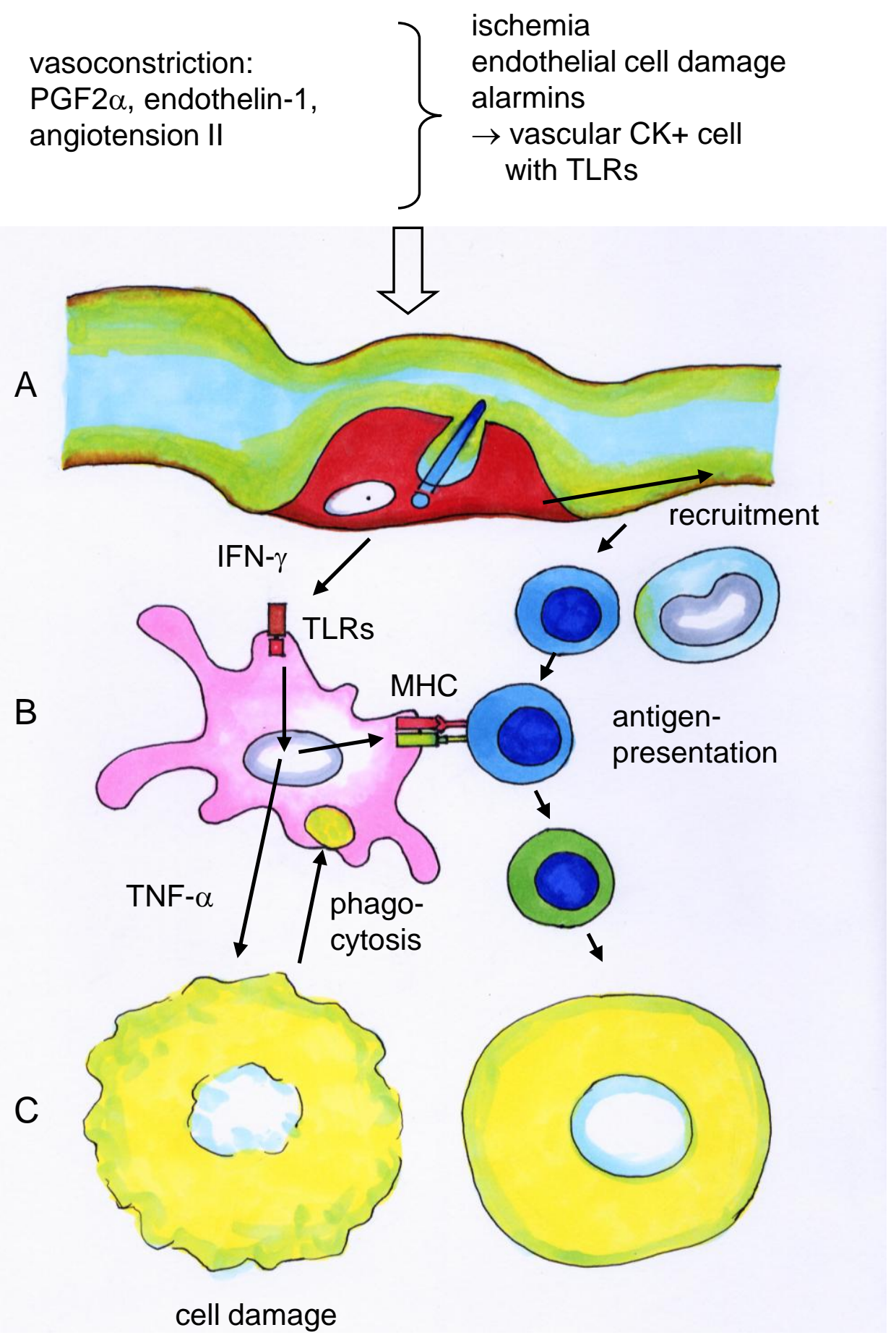

Fig. 2

Spanel-Borowski 